Abstract AB1072 Table 1. Clinical features of patients according to the anatomical classification of uveitis.

\begin{tabular}{|c|c|c|c|c|c|c|}
\hline & & $\begin{array}{l}\text { Anterioruveitis } \\
21 \text { cases } \\
(56.8 \%)\end{array}$ & $\begin{array}{l}\text { Intermediateuveitis } \\
12 \text { cases }(32.4 \%)\end{array}$ & $\begin{array}{l}\text { Posterioruveitis } \\
1 \text { case }(2.7 \%)\end{array}$ & $\begin{array}{l}\text { Panuveitis } \\
3 \text { cases } \\
(8.1 \%)\end{array}$ & $\begin{array}{c}\text { Total } \\
37 \text { cases } \\
(100 \%)\end{array}$ \\
\hline \multirow[t]{2}{*}{ Gender } & Female & $9(24.3 \%)$ & $6(16.2 \%)$ & $1(2.7 \%)$ & $1(2.7 \%)$ & $17(45.9 \%)$ \\
\hline & Male & $12(32.4 \%)$ & $6(16.2 \%)$ & 0 & $2(5.4 \%)$ & $20(54 \%)$ \\
\hline Ocular & Unilateral & $3(8.1 \%)$ & $3(8.1 \%)$ & 0 & $1(2.7 \%)$ & 7 (18.9\%) \\
\hline involvement & Bilateral & $18(48.6 \%)$ & 9 (24.3\%) & $1(2.7 \%)$ & $2(5.4 \%)$ & 30 (81\%) \\
\hline \multirow[t]{5}{*}{ Etiology } & Idiopathic & $13(35.1 \%)$ & $11(29.7 \%)$ & 0 & $2(5.4 \%)$ & $26(70.2 \%)$ \\
\hline & JIA & $5(13.5 \%)$ & 0 & 0 & 0 & $5(13.5 \%)$ \\
\hline & BehcetDisease & 0 & $1(2.7 \%)$ & 0 & $1(2.7 \%)$ & $2(5.4 \%)$ \\
\hline & Sarcoidosis & $1(2.7 \%)$ & 0 & $1(2.7 \%)$ & 0 & $2(5.4 \%)$ \\
\hline & TINU & $2(5.4 \%)$ & 0 & 0 & 0 & $2(5.4 \%)$ \\
\hline
\end{tabular}

Disclosure of Interests: None declared

DOI: 10.1136/annrheumdis-2019-eular.5470

\section{AB1072B THE CONSEQUENCES OF THE PROVISIONAL PAEDIATRIC RHEUMATOLOGY INTERNATIONAL TRIALS ORGANISATION JUVENILE IDIOPATHIC ARTHRITIS CLASSIFICATION CRITERIA}

Vera Mars $^{1}$, Joost F. Swart ${ }^{2}$, Gabriella Giancane ${ }^{3}$, Sytze De Roock ${ }^{2}$, Anne Estmann ${ }^{3}$, Marija Jelusic ${ }^{3}$, Estefania Moreno Ruzafa ${ }^{3}$, Jaime de Inocencio ${ }^{3}$, Jelena Vojinovic ${ }^{3}$, Agustin Remesal $^{3}$, M Laday $^{3}$, Rolando Cimaz ${ }^{3}$, A V. Cochino ${ }^{3}$, Inmaculada Calvo ${ }^{3}, \mathrm{M} \mathrm{Harjacek}^{3}$, Nico Wulffraat $^{2}$, Nicolino Ruperto ${ }^{3} .{ }^{1}$ UMC Utrecht / Utrecht University, Undergraduate / Medical student, Utrecht, Netherlands; ${ }^{2}$ Wilhelmina Children's Hospital / UMC Utrecht, Pediatric Rheumatology, Utrecht, Netherlands; ${ }^{3}$ Paediatric Rheumatology International Trials Organisation, Genova, Italy

Background Last year the International League of Associations for Rheumatology (ILAR) classification criteria for juvenile idiopathic arthritis (JIA), [1] were challenged by the provisional Paediatric Rheumatology International Trials Organisation (PRINTO) classification criteria.[2] Four disorders were proposed: (a) systemic JIA; (b) rheumatoid factor (RF)-positive JIA; (c) enthesitis/spondylitisrelated JIA; and (d) early-onset antinuclear antibody (ANA)-positive JIA. Earlyonset ANA-positive JIA is defined by: arthritis for $\geq 6$ weeks, and early-onset $(\leq 6$ $y r s$ ), and presence of 2 positive ANA tests with a titer $\geq 1 / 160$ at least 3 months apart with the exclusions of having systemic JIA, RF-positive arthritis, or enthesitis/spondylitis-related JIA.

Objectives To evaluate the shifts from the original subtypes of JIA in the new disorder of early-onset ANA-positive JIA.

Methods This study used data from the international PRINTO based registry regarding pharmacovigilance in JIA called Pharmachild.[3] For this analysis we used the data of 4,165 patients completely categorized following the ILAR 'oligoarthritis', 'RF-negative polyarthritis', 'psoriatic arthritis' and 'undifferentiated JIA' (UJIA) subtypes and with complete determination of ANA status. These patients were if possible reclassified in the early-onset ANA-positive JIA according to the provisional PRINTO classification criteria.

Results Table 1 shows the characteristics of all 4,165 patients according to the ILAR criteria. Of this final set of 4165 patients, 1279 (30.7\%) were ANA-positive and 957 (74.8\%) classified into the PRINTO 'early onset ANA-positive JIA' category. Of these 957, 2 patients were RF-positive, which is an exclusion criterion for the 'early onset ANA-positive JIA' category and therefore were not categorized as early onset ANA-positive JIA. The female proportion was higher than in any ILAR subtype being $83.0 \%$ (793/955). The origin (ILAR categories) of the 955 patients in the 'early onset ANA-positive JIA' category consisted of $33.7 \%$ patients with persistent oligoarthritis (322/955), 24.7\% (236/955) with extended oligoarthritis, $28.0 \%$ with RF-negative polyarthritis (267/955), 4.2\% with psoriatic arthritis (40/ 955) and $9.4 \%$ with UJIA (90/955).

$\begin{array}{llllll} & \begin{array}{l}\text { Persistent } \\ \text { OJIA }\end{array} & \begin{array}{l}\text { Extended } \\ \text { OJIA }\end{array} & \begin{array}{l}\text { RF negative } \\ \text { PJIA }\end{array} & \begin{array}{l}\text { Psoriatic } \\ \text { arthritis }\end{array} & \text { UJIA } \\ \begin{array}{l}\text { Total number of } \\ \text { patients, } n(\%)\end{array} & 1283(30.8 \%) & 663(15.9 \%) & 1665(40.0 \%) & 210(5.0 \%) & 344(8.3 \%) \\ \begin{array}{l}\text { Age of disease } \\ \text { onset, years (IQR) }\end{array} & 4.5(2.5-8.3) & 3.7(2.3-1.7) & 6.7(2.9-11.3) & 8.6(3.4-13.3) & 5.7(2.6-10.8) \\ \text { Female, } n(\%) & 968(77.6 \%) & 541(81.6 \%) & 1283(77.1 \%) & 145(69.0 \%) & 228(66.3 \%) \\ \text { ANA positive, } n(\%) & 424(33.0 \%) & 293(44.2 \%) & 384(23.1 \%) & 51(24.3 \%) & 127(26.9 \%)\end{array}$

Table 1. Patient characteristics (4165 patients) divided in ILAR 2001 categories; correctly determined (taking all exclusion criteria into account). OJAA = oligoarticular $J A$, PJIA= polyarticular $J A$

Conclusion This study shows that of all ANA-positive JIA patients belonging to the 'oligoarthritis', 'RF-negative polyarthritis', 'psoriatic arthritis' and 'UJIA' ILAR subtypes, $74.8 \%$ met the criteria for the PRINTO 'early onset ANA-positive' category. The female proportion was higher than in any ILAR subtype being $83.0 \%$ This new category consists largely of 3 ILAR subtypes: persistent oligoarthritis (34\%), extended oligoarthritis (25\%) and RF negative polyarthritis $(28 \%)$. Further studies on these provisional criteria are ongoing.

\section{REFERENCES}

[1] Petty RE, Southwood TR, Manners P et al. International League of Associations for Rheumatology Classification of Juvenile Idiopathic Arthritis: Second Revision, Edmonton, 2001. J Rheumatol. 2014

[2] Martini A, Ravelli A, Avcin T et al. Toward New Classification Criteria for Juvenile Idiopathic Arthritis: First Steps, PRINTO International Consensus. J Rheumatol. 2018 Oct 1

[3] Swart J, Giancane G, Horneff G et al. Pharmacovigilance in juvenile idiopathic arthritis patients treated with biologic or synthetic drugs: combined data of more than 15,000 patients from Pharmachild and national registries. Arthritis Res Ther. 2018 Dec 27

Disclosure of Interests Vera Mars: None declared, Joost F. Swart: None declared, Gabriella Giancane: None declared, Sytze De Roock: None declared, Anne Estmann: None declared, Marija Jelusic: None declared, Estefania Moreno Ruzafa: None declared, Jaime de Inocencio: None declared, Jelena Vojinovic: None declared, Agustin Remesal: None declared, M Laday: None declared, Rolando Cimaz: None declared, A V Cochino: None declared, Inmaculada Calvo Grant/research support from: received research grants from Pfizer, Roche, Novartis, Clementia, Sanofi, MSD, BMS and GSK, Consultant for: Advisory boards: Novartis, AbbVie, Speakers bureau: AbbVie, Roche, Novartis, SOBI, M Harjacek: None declared, Nico Wulffraat: None declared, Nicolino Ruperto Grant/research support from: The Gaslini Hospital, where NR works as full-time public employee, has received contributions ( $>10.000$ USD each) from the following industries in the last 3 years: BMS, Eli-Lilly, GlaxoSmithKline, F Hoffmann-La Roche, Janssen, Novartis, Pfizer, Sobi. This funding has been reinvested for the research activities of the hospital in a fully independent manner, without any commitment with third parties., Consultant for: Received honoraria for consultancies or speaker bureaus ( $<10.000$ USD each) from the following pharmaceutical companies in the past 3 years: Ablynx, AbbVie, Astrazeneca-Medimmune, Biogen, Boehringer, BristolMyers Squibb, Eli-Lilly, EMD Serono, GlaxoSmithKline, Hoffmann-La Roche, Janssen, Merck, Novartis, Pfizer, R-Pharma, SanofiServier, Sinergie, Sobi and Takeda., Speakers bureau: Received honoraria for consultancies or speaker bureaus (< 10.000 USD each) from the following pharmaceutical companies in the past 3 years: Ablynx, AbbVie, Astrazeneca-Medimmune, Biogen, Boehringer Bristol-Myers Squibb, Eli-Lilly, EMD Serono, GlaxoSmithKline, Hoffmann-La Roche, Janssen, Merck, Novartis, Pfizer, R-Pharma, SanofiServier, Sinergie, Sobi and Takeda.

DOI: 10.1136/annrheumdis-2019-eular.1958

\section{AB1072C CHILDREN WITH JUVENILE IDIOPATHIC ARTHRITIS THE CORRELATION BETWEEN CAROTID INTIMA-MEDIA THICKNESS AND MARKERS OF INFLAMATION TO DETERMINE PRE-CLINICAL ATHEROSCLEROSIS}

Mustafa Armut ${ }^{1}$, Ruhan Düşünsel ${ }^{2}$, Aysenur Pac Kisaarslan ${ }^{2}$, Gonca Koç ${ }^{3}$, Betül Sözeri ${ }^{2}$, Ferhan Elmalı ${ }^{4}$, Muammer Hakan Poyrazoglu ${ }^{2}$, Zubeyde Gunduz ${ }^{2}$. ${ }^{1}$ Erciyes University Faculty of Medicine, Pediatrics, Kayseri, Turkey; ${ }^{2}$ Erciyes University Faculty of Medicine, Pediatric Rheumatology, Kayseri, Turkey; ${ }^{3}$ Erciyes University Faculty of Medicine, Pediatric Radiology, Kayseri, Turkey, ${ }^{4}$ izmir Katip Celebi University, Bioistatistic, Izmir, Turkey

Background: Juvenile idiopathic arthritis (JIA) is the most common chronic rheumatic disease in childhood. JIA is a heterogeneous group of disorders with different disease progression and prognosis. Cardiovascular 